\title{
The Influence of Leverage, Cash Flow, Tax, R \& D, Economic Growth and Inflation on the Financial Distress in the Sub-Sector of Property and Real Estate Companies
}

\author{
Khirstina Curry* \\ Faculty of Economics and Business \\ Universitas Trisakti \\ Jakarta, Indonesia \\ *k.curry04@gmail.com
}

\begin{abstract}
This study aims to estimate and analyse the influence of leverage, cash flow, tax, R\&D, economic growth, and inflation on financial distress in the property and real estate companies' sub-sector. The first four attributes form the internal factors of the company, while the remaining is external with the research data obtained from a 2014 to 2018 using the panel data regression as a method. Only a few study uses company internal and external factors simultaneously. The results showed that leverage and cash flow are internal factors with adverse influences on the occurrence of financial distress. Furthermore, economic growth is an external factor that influences the financial distress in the sub-sector of property and real estate companies listed on the IDX. In conclusion, Tax, R\&D, and inflation do not influence financial distress.
\end{abstract}

Keywords-financial, growth, leverage, tax, inflation

\section{INTRODUCTION}

A country's financial state is solely dependent on its economy, which tends to positively or negatively affect the progress and welfare of its people. Therefore, poor economic conditions often lead to financial distress and bankruptcy in companies [1].

However, lots of policies have been issued by the government to encourage and revive the property market. For instance, in 2015, the easing policy on Loan to Value (LTV) of KPR (Home Ownership Credit) and revision on Minister of Finance Regulation (PMK) No. 106/PMK.010/2015 on Luxury Taxable Goods, and Economic Policy Package Volumes 1 and 5 were issued. These policies are expected to increase property loan growth, and subsequently lead to a rise in investment and economic growth in Indonesia.
The property bubble that regularly occurs in the local market, is characterized by a rapid increase in the prices till it reaches the maximum level as shown in 2008.Based on the property prices index in the Greater Jakarta area, 2009-2014 was a booming period in which the increase in property prices reached almost $150 \%$. The second quarter of 2016 and 2017 slowed down, by $4 \%-5 \%$ per year.

Figure 1 shows the growth of property and real estate stock prices from 2013 to 2017 . The highest and lowest stock price indexes occurred of Rp 5,219,336, and Rp 4,125,292 occurred in 2016 and 2014, respectively. Therefore, the investors' interest increases in investing their wealth, which is strongly supported and facilitated by investors.

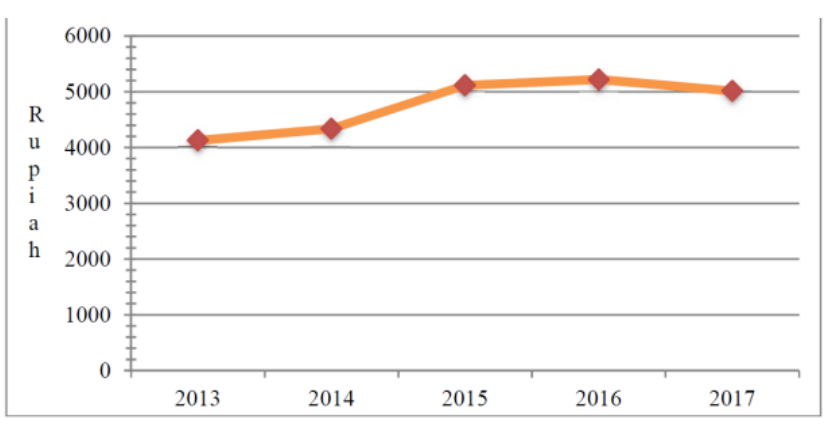

Fig. 1. Property and real estate stock price index from 2013 to 2017.

The increase in the stock price index and the Government's policy needs to encourage property growth. However, some companies still earn losses. Table 1 shows a list of property and real estate companies with losses from 2014-2017. The result showed that some companies suffered losses for 3 years in a row without significant changes due to internal and external financial distress. 
TABLE I. L LIST OF COMPANIES WITH Negative Profit (LOSS) FOR THE 2014-2017 PerIod

\begin{tabular}{|l|l|l|l|l|l|}
\hline \multirow{2}{*}{ No } & \multirow{2}{*}{ Code } & \multicolumn{4}{|c|}{ Net Profit (Loss) for the Current Year (Rp) } \\
\cline { 3 - 6 } & & \multicolumn{1}{|c|}{$\mathbf{2 0 1 4}$} & \multicolumn{1}{|c|}{$\mathbf{2 0 1 5}$} & \multicolumn{1}{|c|}{$\mathbf{2 0 1 6}$} & \multicolumn{1}{|c|}{$\mathbf{2 0 1 7}$} \\
\hline 1 & BIPP & 34.702 .780 .455 & 42.766 .582 .156 & 27.224 .420 .762 & $(31.033 .697 .167)$ \\
\hline 2 & BKPD & 7.031 .603 .218 & $(28.227 .002 .713)$ & $(28.948 .289 .175)$ & $(43.170 .166 .331)$ \\
\hline 3 & COWL & 164.635 .880 .360 & 9178.692 .186 .724 & $(3.451 .334 .960)$ & $(69.033 .208 .868)$ \\
\hline 4 & ELTY & 424.757 .565 .296 & $(931.612 .045 .312)$ & $(931.612 .045 .312)$ & $(931.612 .045 .312)$ \\
\hline 5 & LCGP & 17.473 .275 .338 & $(654.073 .792)$ & 3.139 .928 .220 & $(12.394 .679 .065)$ \\
\hline 6 & MTSM & $(1.131 .879 .462)$ & $(4.678 .222 .844)$ & $(2.364 .989 .127)$ & $(4.802 .932 .780)$ \\
\hline 7 & NIRO & $(108.501 .147 .457)$ & $(28.006 .832 .509)$ & $(31.336 .684 .656)$ & 3.721 .787 .876 \\
\hline 8 & OMRE & 109.787 .785 .623 & $(22.135 .914 .169)$ & 318.395 .155 .443 & $(66.193 .842 .560)$ \\
\hline 9 & RBMS & 3.006 .840 .129 & $(3.085 .639 .160)$ & $(6.713 .147 .549)$ & 14.519 .780 .720 \\
\hline
\end{tabular}

The factors responsible for financial distress known as the Basic Model of Bankruptcy or the Trinity of Causes are divided into three groups [2]. The first is the neoclassical model, which occurs due to the improper management in allocating resources (assets) used for operations within the company. The second is the financial model, which tends to properly manage the assets of a company without using the right financial structure due to its liquidity constraints. Therefore, the company has the ability to survive over an extended period. The third is the corporate governance model, which stated that most companies with good assets and financial structures are poorly managed.

Financial distress also occurs due to the low ability of companies to generate profits from its operations [3]. This is caused by external deterioration or the failure of internal control, thereby leading to bankruptcy and loss on large and small scale industries [4,5]. It has significant consequences capable of reducing a company's economy, hence, investors and creditors tend to lose their monies [6].

Another factor that causes financial distress is the macroeconomic condition of a country, inflation, interest rates, and the devaluation of the rupiah currency to the dollar (exchange rate) [7].

The fluctuated inflation rates in table 2 show that the inflation in Indonesia is unstable. This leads to a decrease in its currency value, which negatively impacts on individuals, businesses, revenues, and expenditure budgets [8].

TABLE II. ANNUAL INFLATION RATE IN THE PERIOD OF 2013-2017

\begin{tabular}{|l|l|}
\hline \multicolumn{1}{|c|}{ Year } & $\begin{array}{c}\text { Inflation Rate (in } \\
\text { percentage) }\end{array}$ \\
\hline 2013 & 8,38 \\
\hline 2014 & 8,36 \\
\hline 2015 & 3,35 \\
\hline 2016 & 3,02 \\
\hline 2017 & 3,61 \\
\hline \multicolumn{2}{|c|}{ Source: Bank Indonesia Inflation Report 2019 }
\end{tabular}

Financial ratio analysis is a tool used to measure a company's value. However, their unpreparedness in predicting these conditions leads to bankruptcy. Financial distress starts when a company is unable to its payment or cash flow obligations, thereby, leading to bankruptcy or liquidation [2,9].
A research was conducted on the influence of liquidity, leverage, and profitability to financial distress in a total of 118 manufacturing companies listed on the Stock Exchange from 2013-2018 [8]. The results showed that an increase in the three independent variables led to a decrease in financial distress. This study, therefore, analyses the influence of leverage, cash flow, tax, R\&D, economic growth, and inflation on financial distress.

\section{LITERATURE REVIEW}

Financial distress is defined as the decrease in the financial condition of a company, which occurs before bankruptcy or liquidation [10]. It is also defined as the inability of a company to pay off financial obligations on time.

\section{A. The Relationship between Leverage and Financial Distress Ratios}

The leverage ratio measures the level of assets in a company and its ability to fulfil its obligations in the short and long term. It is used as a proxy for debt to assets ratio, which triggers the occurrence of financial distress, due to an increase in the company's ability to cover the obligations and interest charged [10]. The leverage coefficients and the predictors of corporate financial distress are negative [11]. Based on the theory and previous research, the hypothesis is formulated as follows:

H1: Debt to assets ratio is used to predict the company's financial distress.

One of the financial information seen by investors is the cash flow disclosed in their financial statements. Assuming the net cash provided by operating activities is high, the company is able to generate sufficient funds internally from operations to pay its obligations without having to borrow. This is categorized as a positive signal. Conversely, when the net cash generated by the operating activities is low, the company is unable to generate sufficient funds internally from its operations, and this is categorized as a negative signal. The creditor tends to desist from entrusting their credit to the company, with the continuous occurrence of the financial distress. This is supported by Almilia [12], which showed that cash flow influences financial distress. Therefore, based on the above description, the hypothesis is formulated as follows:

$\mathrm{H} 2$ : Cash flow influences financial distress. 
Research on the relationship between R\&D and financial distress conducted by some researchers showed positivity between liquidity and financial distress $[13,14]$. Furthermore, the results stated there is a negative relationship influences financial distress costs, while determining the total short and long-term debt. Based on this, the following hypothesis was formulated as follows:

\section{H3: R\&D influences financial distress.}

Studies stated that macroeconomic variables such as interest rate, tax, inflation, and GDP growth influence the risk of financial distress $[12,15]$. Based on the theory and previous research, the following hypothesis are formulated as follows:

H4: Tax influences financial distress.

H5: Economic growth influences financial distress.

The higher the inflation rate of a country, the more difficult its financial conditions due to an increase in the prices of goods. Based on Iramani [16], the sensitivity of macroeconomic conditions (inflation) has the ability to influence the occurrence of financial distress. According to $[17,18]$, inflation does not influence financial distress, which led to the following hypothesis.

H6: Inflation influences financial distress.

\section{METHODS}

Leverage is a ratio used to measure the company's ability to fulfil the obligations both in the short or long term. This research utilized the debt to asset ratio (DAR) to fulfil their short and long term obligations. Therefore, the leverage conceptually measured the debt ratio with the owned asset. Generally, a well-financed company has a DAR ratio of less than or equal to 1 . However, an increase in the ratio, leads to a higher debt ratio level owned by a company. The formula of DAR ratio is as follows:

\section{$\mathrm{DAR}=$ Total debt/Total asset}

The cash flow used is the amount of expenditure for each period, including the purchase of materials and equipment, excluding revenue. Indicator of $R \& D$ expenditures is measured in the year where the costs are charged.

\section{$R \& D$ Expenditures $=\operatorname{Ln}(R \& D$ Expenditures in the year $)_{t}$}

The tax used is the tax paid by the company annually. The measurement of economic growth used is the difference in the current year's GDP with the previous i.e., Growth $=G D P_{t}-$ $G D P_{t-1} / G D P_{t-1}$

The measure used is the average annual inflation obtained from publications results of the Bank Indonesia from 20142018. The panel data is a combination of cross section and time series, as shown with the following equations:
Yit $=\alpha+\beta$ Xit $+\varepsilon$ it; $i=1,2, \ldots, N ; t=1,2, \ldots . ., T$

where:

$$
\begin{aligned}
& \mathrm{N}=\text { total observations } \\
& \mathrm{T}=\text { total time } \\
& \mathrm{N} \times \mathrm{T}=\text { total panel data }
\end{aligned}
$$

In general, panel data produces different intercepts and slope coefficients in each company and at a certain time. Therefore, estimating equation (3) is dependent on the assumptions on intercept, slope coefficient, and the interference variable.

Three tests are used to choose the panel data estimation technique [9]. The first is the F statistical test is used to choose between the Common Effect or Fixed Effect methods. This is followed by the Hausman test used to choose between the Fixed or Random Effect methods. Thirdly, the Lagrange Multiplier (LM) test is used to choose between the Common or Random Effect methods.

\section{RESULTS AND DISCUSSION}

\section{A. Result}

The results of this study showed that the adjusted Rsquared is 0.995000 . It means that the variation in the influence of leverage, cash flow, R\&D, tax, economic growth, and inflation on financial distress is 99.50 percent. Meanwhile, the remaining 0.5 percent is influenced by other factors.

The probability of the F Test is 0.000000 , which showed that the model of this study is in good fit condition. The equation formed from this research is as follows:

$\mathrm{FD}=0.285714-1,54 \mathrm{DAR}-5,28 \mathrm{CSF}-1,09 \mathrm{Tax}-9,05 \mathrm{RD}-8,76 \mathrm{Growth}+5,14 \mathrm{Inflation}$

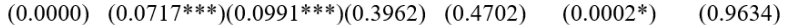

The t-test shows that: DAR, CSF, and Economic Growth influence financial distress, as opposed to Tax, R\&D, and Inflation.

\section{B. Discussion}

Leverage (DAR) has a negative influence on financial distress, which increases due to a decrease in its rate. A high DAR value does not always have a high probability of financial distress because companies with greater levels of debt tend to fulfil their asset purchases and increase company profits. The research results of several researchers $[10,11,19,20]$ are also supported by Alifiah [17]. A study reports that leverage coefficients are negative and predictors of corporate financial distress. The findings are supported by this researchers $[10$, $11]$.

Cash flow has a negative influence on financial distress, with a good flow, indicating that the company has generated sufficient funds to pay off the loan, maintain the operating ability of the entity, pay dividends, and make new investments 
without the help of external funding sources. Therefore, creditors receive a positive signal, and the company has no potential to experience financial distress.

$\mathrm{R} \& \mathrm{D}$ plays an essential role in developing innovation in company productivity to achieve its predetermined goals. Furthermore, it is expected to increase the company's productivity, growth, and long-term performance every year [21]. Therefore, many companies are interested in conducting R\&D activities, because an increase in the research and development budget, leads to a possible rise in the ratio of asset returns and performance [22]. However, this is different from the results of this study, which show that R\&D does not influence financial distress because companies have failed to pay full attention to its existence. Therefore, the amount of R\&D expenditure does not influence the occurrence of financial distress.

From the four macro variables, economic growth is the only variable that influences financial distress. This is because when the economy grows, the company also grows as indicated by an increase in sales and income, thereby, reducing financial distress.

Inflation does not influence financial distress because it tends to affect the price of goods and the purchasing ability of consumers, thereby reducing the company's sales turnover. Inflation is a tendency to increase prices of a good number of goods and services generally and continuously. With inflation, the price of goods increases, therefore, people's purchasing power and their welfare level decrease. The results of this study are in line with [23], which found a significant and insignificant relationship between inflation and financial distress.

\section{CONCLUSION}

In conclusion, Leverage (DAR), Cash Flow (CSF), and Economic Growth (Growth) all have a negative influence on financial distress, with positivity on Tax, R\&D, and Inflation. Therefore, the internal factors have a greater influence than the external.

\section{REFERENCES}

[1] E. Afriyeni, "Model Prediksi Financial Distress Perusahaan," Polibisnis, vol. 4 , no. 2, pp. 1-10, 2012.

[2] K.A. Fachrudin, Kesulitan Keuangan Perusahaan dan Personal. Medan: USU Press, 2008

[3] N.A. Shaari, N.A. Hasan, Y.R. Palanimally and D.R. Mohamed, "The Determinants of Derivative Usage: A Study on Mallaysian Firms," Interdisciplinary Journal of Contemporary research In Business, vol. 5, no. 2 , pp. 300-316, 2013.

[4] Y. Zhang, C. Wu and Z. Xin-ying, "Enterprise Financial Distress Prediction Based on BPNN: A Case Study of Chinese Listed
Companies," Information Technology Journal, vol. 12, no. 23, pp. 7684-7690, 2013.

[5] M. Sheikhi, M.F. Shams and Z. Sheikhi, "Financial distress prediction using distress score as a predictor," International Journal of Business and Management, vol. 7, no. 1, pp. 169, 2012.

[6] A. Habib, B.U. Bhuiyan and A. Islam, "Financial distress, earnings management and market pricing of accruals during the global financial crisis," Managerial Finance, vol. 39, no. 2, pp. 155-180, 2013.

[7] D.K. Liou and M. Smith, Macroeconomic Variables in the Identification of Financial Distress, 2006.

[8] A.K. Masyhuri, P.R. Widodo and G.S. Rokhimah, "Penerapan kebijakan moneter dalam kerangka inflation targeting di Indonesia," Ser Kebanksentralan, vol. 21, 2008.

[9] Widarjo, Wahyu dan Setiawan, Doddy, "Pengaruh Rasio Keuangan Terhadap Kondisi Financial Distress Perusahaan Otomotif", Jurnal Bisnis dan Akuntansi. 11 (2) : 107-119, 2009.

[10] Platt, H. D., \& Platt, M. B., "Predicting corporate financial distress: reflections on choice-based sample bias. Journal of economics and finance, 2002, 26(2), 184-199.

[11] Yap, B. C. F. 2012. Evaluating Company Failure in Malaysia Using Financial Ratios and Logistic Regression. Asian Journal of Finance and Accounting 4(1): 330-344

[12] Almilia, L. S. 2006. Prediksi Kondisi Financial Dsitress Perusahaan Go Public dengan Menggunakan Analisis Multinomial Logit. Jurnal Ekonomi dan Bisnis. Vol X11 No 1.

[13] John, T.A., Accounting measures of corporate Liquidity, Leverage and Costs of Financial Distress. Financial management, 1993, 22(3), 91-101.

[14] Opler T. C. and Titman S., "Financial Distress and Corporate Performance. The Journal of Finance", 2012, 4(3), 1015-1040.

[15] Tirapat, Suntil dan Nittayagasetwat, Aekkachai, An Investigation of Thai Listed Firms' Financial Distress Using Macro and Micro Variables, Multinational Finance Journal, 1999, Vol 3, No. 2 pp 103-125

[16] Rr. Iramani, "Model Prediksi Financial Distress Perusahaan Go Public di Indonesia (Studi pada Sektor Manufaktur)", Jurnal Aplikasi Manajemen. Vol. 6. No. 1. April 2008.

[17] M.N. Alifiah, "Prediction Financial Distres Companies in the Trading and Service Sector in Malaysia Using Macroeconomic Variables," Procedia - Social and Behavioral Sciences, vol. 129, pp. 90-98, 2014

[18] D. Surya, “Analisis Pengaruh Corporate Governance, Variabel Ekonomi Makro terhadap Financial Distress dengan Variabel Kontrol Ukuran Perusahaan dan Jenis Kepemilikan,” Efektif Jurnal Ekonomi dan Bisnis, vol. 7 , no. $1,2017$.

[19] O. Gobenvy, "Pengaruh Profitabilitas, Financial Leverage dan Ukuran Perusahaan terhadap Financial Distress pada Perusahaan Manufaktur yang Terdaftar di Bursa Efek Indonesia Tahun 2009-2011," Jurnal Akuntansi, vol. 2, no. 1, 2014.

[20] H.R. Silalahi, F.T. Kristanti and M. Muslih, "Pegaruh Rasio Keuangan dan Ukuran Perusahaan Terhadap Kondisi Kesulitan Keuangan (Financial Distress) pada Perusahaan sub-sektor transportasi yang terdaftar di Bursa Efek Indonesia (BEI) Periode 2013-2016," Eproceeding of Management, vol. 5, no. 1, 2018

[21] E. Pantagakis, D. Terzakis and S. Arvanitis, "R\&D investments and firm performance: An Empirical Investigation of the High Technology Sector (Software and Hardware) in the EU, pp. 1-20, 2012.

[22] A. Ghaffar and W.A. Khan, "Impact of Research and Development on Firm Performance," International Journal of Accounting and Financial Reporting, vol. 4, no. 1, 357-367, 2014.

[23] N. Nurhidayah and F. Rizqiyah, "Kinerja Keuangan dalam Memprediksi Financial Distress,” Jurnal JIBEKA, vol. 11, no. 1, 2017. 